\title{
Growth and Yield Performance of Five Guar Cultivars in a Mediterranean Environment
}

\author{
Orazio Sortino, Fabio Gresta* \\ Dipartimento di Scienze Agronomiche, Agrochimiche e delle Produzioni Animali, Università di Catania \\ Via Valdisavoia 5, 95123 Catania, Italy
}

Received: 20 April 2007. Accepted: 9 September 2007.

\begin{abstract}
In order to evaluate growth and yield performance of guar (Cyamopsis tetragonoloba L.) in Mediterranean area, main morphological parameters (plant height, dry weight of single plant parts, branch and leaf number), dry biomass accumulation and seed yield response of five varieties of guar (Esser, Malosan, Kinman, Lewis and Santa Cruz) were studied. Seed crude protein and fibre content were also determined. Irrigation was applied to ensure that water availability did not limit production. The growing season of guar lasted for 120 days for all the varieties. Average plant height at harvest was about $63 \mathrm{~cm}$ (ranging from 56.0 to $70.6 \mathrm{~cm}$ ). The highest dry weight increment was recorded during 55-70 days after sowing. Malosan, Santa Cruz and Kinman showed the highest individual seed weight $(>30 \mathrm{mg})$. Above average leaf and branch number were observed in Kinman, Esser and Santa Cruz. The greatest seed protein content was observed in Lewis and Esser (35.6\% and 34.7\%). High yield and seed quality were obtained in these environments with limited water supply, indicating that guar may represent a valid alternative multipurpose crop for semiarid regions.
\end{abstract}

Key-words: Guar, dry biomass, seed yield, agronomic characteristics, seed protein and fibre content.

\section{Introduction}

Guar (Cyamopsis tetragonoloba L.) is a summer, annual, drought-tolerant legume. Although doubts remain about its centre of origin, guar probably originated and developed in the arid areas of the Indo-Pakistan subcontinent (Whistler and Hymowitz, 1979). It needs a hot climate, takes advantage of irrigation (Alexander et al., 1988) and fertilization (Omer et al., 1993), has a high tolerance to salinity (Ashraf et al., 2005; Francois et al., 1990) and a good capability to fix atmospheric nitrogen (Wetselaar, 1967; Elsheikh and Ibrahim, 1999). Guar seeds contain about 4\% edible oil (Mehta and Ramakrishanan, 1957), and a protein content ranging between 27 and 37\% (Whistler and Hymowitz, 1979). Although it is an industrial crop, it is also cultivated as a vegetable for human consumption, particularly in India and Pakistan, as feed for livestock and as a green manure crop. From the seed endosperm, guar gum (long branching polymers of manose and galactose) is extracted and used in a wide range of industrial destination, but mainly in food industry as a flocculant and binder in ice cream and frozen desserts. Recently, guar gum has also been studied as a substitute for fat in human food (Zambrano et al., 2004) to decrease total caloric content. Guar gum is also used in paper, pharmaceutical and cosmetics industry. After gum extraction, the residue or guar meal, is utilisable as food for cattle due to its high protein content.

Guar is best adapted to tropical and subtropical regions. It is mainly cultivated in India, Pakistan and USA (Texas and Oklahoma). In Europe, it has been grown in the past in Italy, where details were reported for late sowing in Sicily (Whyte et al., 1953), but it is no longer grown in this region. Due to high drought and salinity tolerance, guar could be a valuable al-

\footnotetext{
* Corresponding Author: Tel.: +39 095 234471; Fax +39 095 234449. E-mail address: fgresta@unict.it
} 
ternative crop for the exploitation of the semiarid environments (Losavio et al., 1995), where high temperature, poor erratic rainfall and elevated water salt content do not allow the cultivation of many crops. However, very little research has been carried out in Mediterranean countries to study the agronomic response of this crop. The aim of this research was to evaluate dry biomass accumulation, seed yield and qualitative characteristics of five cultivars of guar in the Mediterranean environment.

\section{Material and methods}

The research was carried out in Parabuto (Sicily, south Italy, $550 \mathrm{~m}$ above m.s.l. $36^{\circ} 55^{\prime} \mathrm{N}$, $14^{\circ} 45^{\prime}$ E) on a well drained soil (sand $39 \%$, loam $24 \%$, clay $37 \%$ ) using the following cultivars: Esser, Malosan, Kinman, Lewis and Santa Cruz. Four replicate $20 \mathrm{~m}^{2}$ plots were sown in a randomized complete block design. Sowing was carried out on 17 June 2002, with a spacing of $50 \mathrm{~cm}$ between the rows and $8 \mathrm{~cm}$ between the plants, equivalent to 25 plants $\mathrm{m}^{-2}$. At sowing, 20 $\mathrm{kg} \mathrm{ha}^{-1}$ of $\mathrm{N}, 40 \mathrm{~kg} \mathrm{ha}^{-1}$ of $\mathrm{P}_{2} \mathrm{O}_{5}$ and $30 \mathrm{~kg} \mathrm{ha}^{-1}$ of $\mathrm{K}_{2} \mathrm{O}$ were supplied. From June to September, $2,010 \mathrm{~m}^{3} \mathrm{ha}^{-1}$ of water was supplied with a drip system, restoring $100 \%$ of the $\mathrm{ET}_{\mathrm{m}}$ (maximum evapotranspiration), crop water use calculated by a class A pan evaporation, using the soybean coefficients (Doorenbos and Kassam, 1979). Weed control was managed by chemical treatment before sowing (Trifluralin, $8.81 \mathrm{ha}^{-1}$ ) and by hand weeding during the trial. Phenological phas-

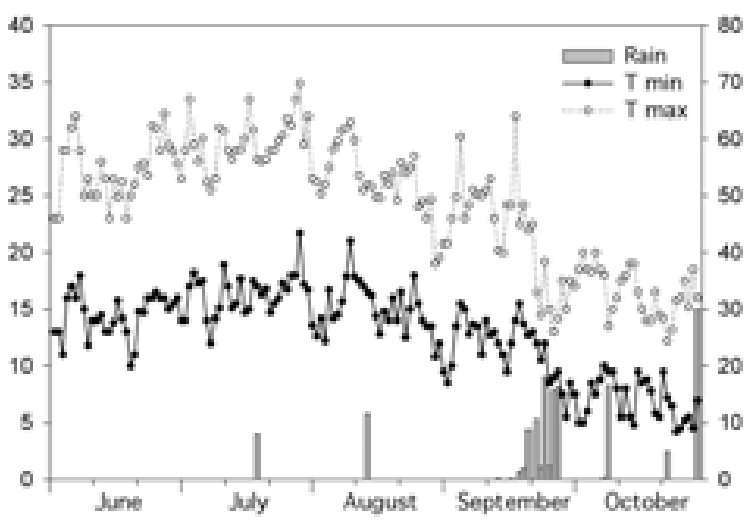

Figure 1. Temperature and rainfall at the experimental location (Parabuto $550 \mathrm{~m}$ above m.s.l.) during the trial. Each point represents one day.

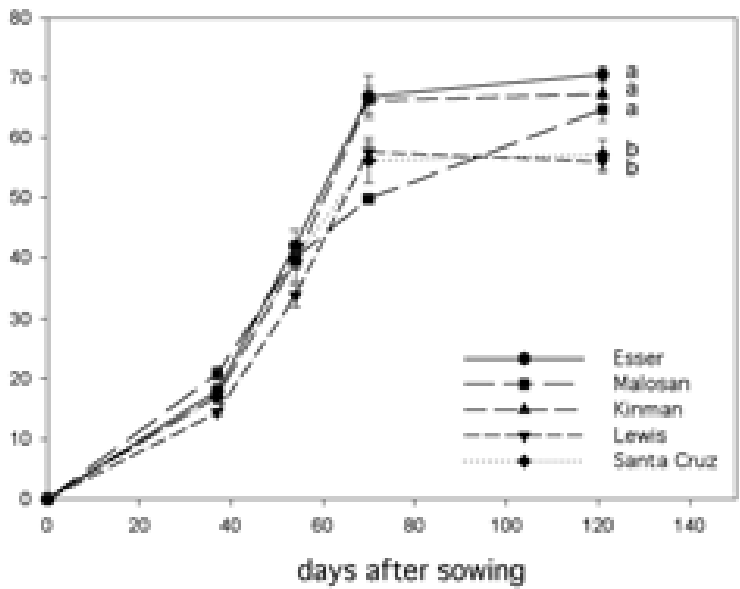

Figure 2. Plants height during the biological cycle, 17 June $=$ day 1 . Vertical bars indicate standard error. Different letters are significantly different $(\mathrm{P}<0.05)$.

es and growth were analysed, recording the main biometric (height of plants, number of branches, number of leaves) and production (seed yield and seed weight) parameters. Dry weight accumulation of different plant parts (stem, branches, leaves and pods) at 37, 54, 70 and 121 days after sowing (DAS) was measured in ten plants for each plot. Crop growth rate (CGR) for each growing period was calculated. Protein (Kjeldahl) and fibre contents (Weende) of seeds were also determined (AOAC, 1995). Temperature and rainfall were monitored throughout the experiment. Data were analysed by a one-way ANOVA using the Students-Newman and Keuls test (SNK) with Costat package (CoHort Software).

\section{Results}

\subsection{Temperatures and rainfall}

Air temperature fluctuations were representative of the thirty year data. During vegetative plant growth, temperatures rarely dropped to 10 ${ }^{\circ} \mathrm{C}$ or were greater than $35^{\circ} \mathrm{C}$. During ripening, a considerable reduction in both minimum and maximum temperatures was observed. During the experiment, rainfall was $110 \mathrm{~mm}$, concentrated in the second half of September (Fig. 1).

\subsection{Biometric parameters}

All the varieties showed a similar plant height trend; the fastest growing period was recorded between $40^{\text {th }}$ and $70^{\text {th }}$ (DAS) at which plants 
reached almost their final height, except Malosan which continued growing until harvest (121 $1^{\text {st }}$ DAS) (Fig. 2). At harvest Esser, Malosan and Kinman were significantly taller $(67.5 \mathrm{~cm}$ on average), than Lewis and Santa Cruz (56.5 $\mathrm{cm}$ on average).

Dry weight analysis of the whole plant showed increasing values until harvest, where a peak of 20.9 g plant $^{-1}$ of dry matter on average was reached (Fig. 3). The highest dry weight increment was recorded during 55-70 DAS, in all varieties but particularly in Kinman and Esser, reaching 18.5 and $17.5 \mathrm{~g} \mathrm{plant}^{-1}$ respectively, while Malosan and Santa Cruz had the lowest, of 12.4 and $11.9 \mathrm{~g} \mathrm{plant}^{-1}$ respectively. Varieties did not show statistical differences for dry weight at the end of the cycle ( $121^{\text {st }}$ DAS), ranging between 24.2 g plant $^{-1}$ of Kinman and 17.2 g plant $^{-1}$ of Santa Cruz.

Leaves showed the highest value of dry matter at $70^{\text {th }}$ DAS and decrease to 0 in the following period because of dropping. Leaf dry weight ranged between $7.5 \mathrm{~g}_{\text {plant }}^{-1}$ in Kinman to $3.56 \mathrm{~g} \mathrm{plant}^{-1}$ in Santa Cruz. Main stem dry weights never exceeded the $3.0 \mathrm{~g}^{\text {plant }}{ }^{-1}$ registered for Kinman at $121^{\text {th }}$ DAS with no differences between varieties. Branch dry weight ranged between 2.6 and $5.3 \mathrm{~g} \mathrm{plant}^{-1}$, respec-
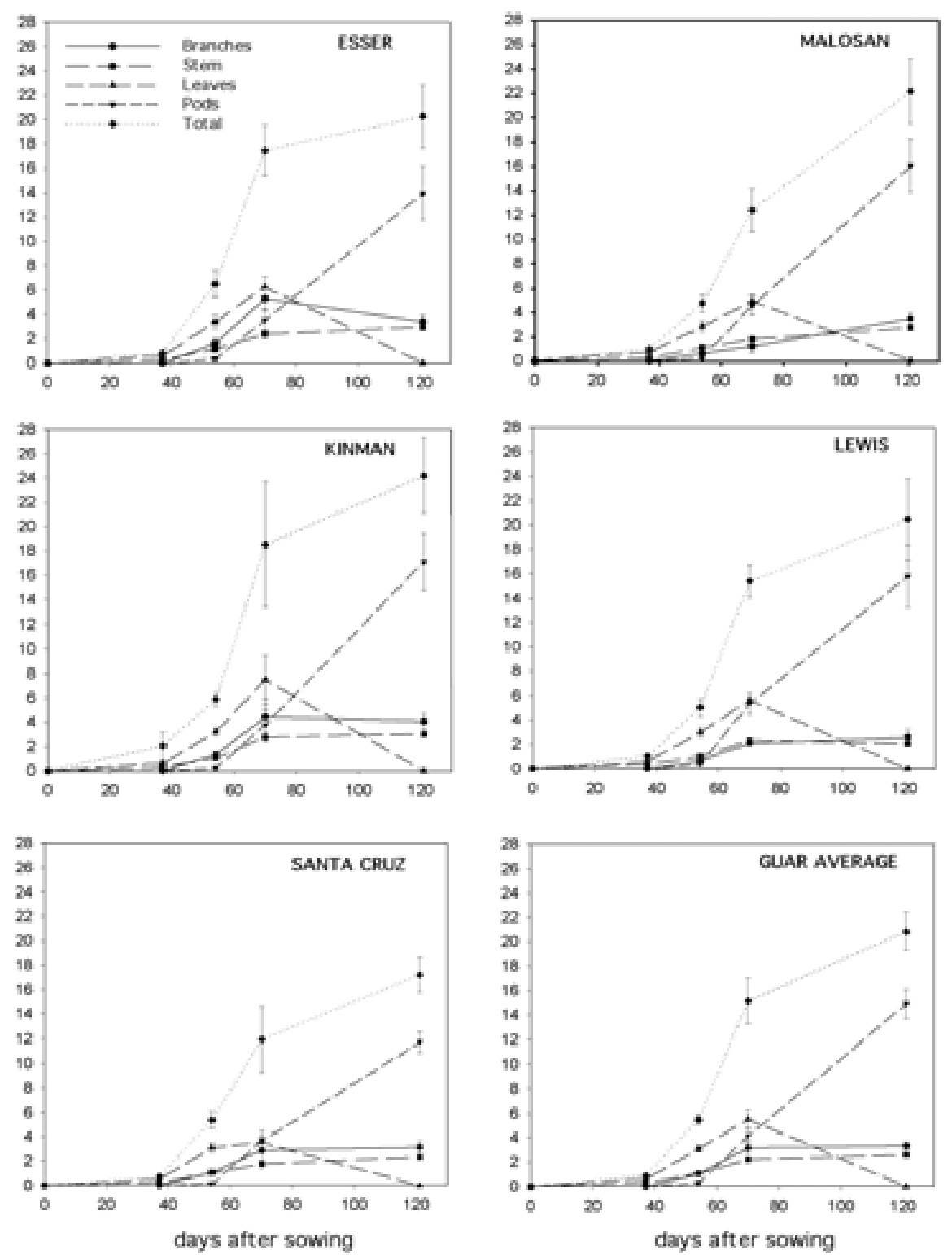

Figure 3. Dry weight (g plant $\left.^{-1}\right)$ of the different plant parts for each variety. Vertical bars indicate standard error. 


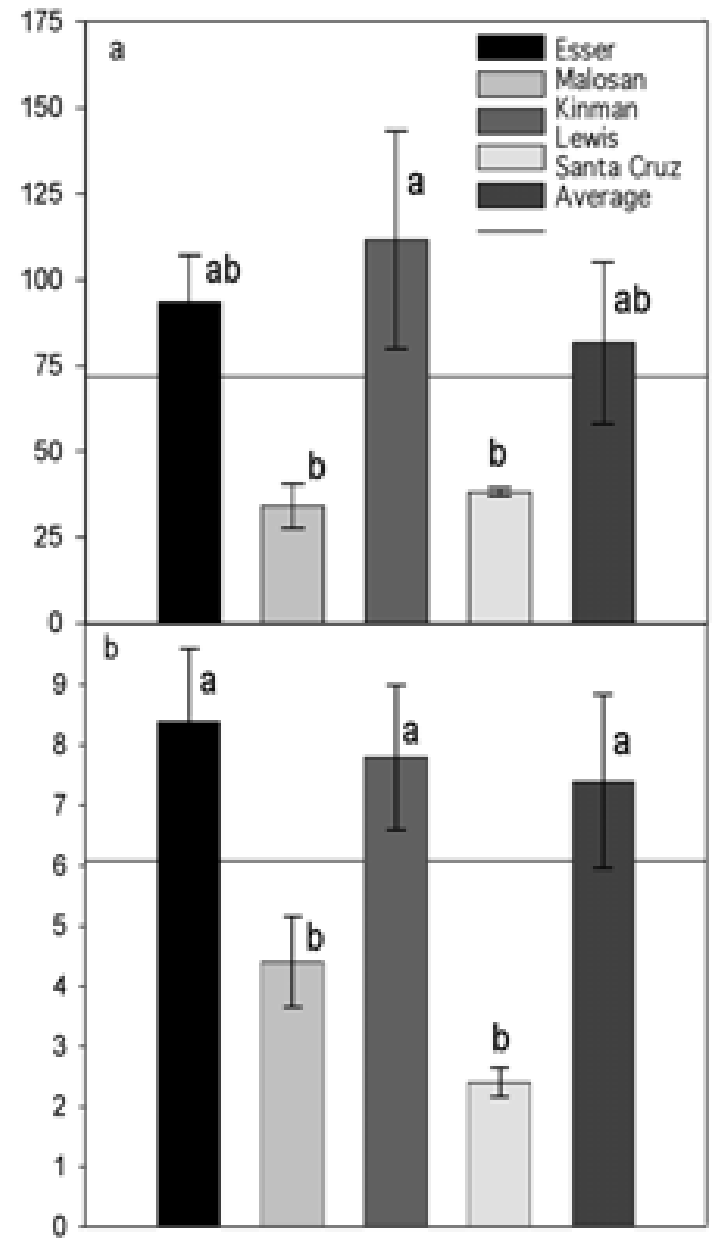

Figure 4. Leaf and branch number at 70 days after sowing. Vertical bars indicate standard error. Different letters are significantly different $(\mathrm{P}<0.05)$.

tively, for Lewis and Esser, while pods showed, at the end of the cycle, average values of $14.9 \mathrm{~g}$ plant $^{-1}$ (ranging from $11.7 \mathrm{~g} \mathrm{plant}^{-1}$ for Santa Cruz and $17.1 \mathrm{~g} \mathrm{plant}^{-1}$ for Kinman).

At $70^{\text {th }}$ DAS, higher values of both leaf and branch numbers were observed in Kinman, Esser and Santa Cruz (95.5 and 7.9 on average, respectively) (Fig. 4a and b).

CGR values showed a different growing trend in the studied varieties: in Esser a high CGR in the $2^{\text {nd }}$ and $3^{\text {rd }}$ period and low in the $4^{\text {th }}$ period $\left(8.3,17.1\right.$ and $1.4 \mathrm{~g} \mathrm{~m}^{-2} \mathrm{~d}^{-1}$, respectively) was achieved, in contrast to Malosan in which an opposite behaviour was recorded (5.5, 12.0 and $4.8 \mathrm{~g} \mathrm{~m}^{-2} \mathrm{~d}^{-1}$, respectively). Kinman shows the highest CGR index in the $3^{\text {rd }}$ period $\left(19.8 \mathrm{~g} \mathrm{~m}^{-2} \mathrm{~d}^{-1}\right)$ (Tab. 1).
Table 1. Crop growth rate $\left(\mathrm{g} \mathrm{m}^{-2} \mathrm{~d}^{-1}\right)$ of the studied varieties for each growing period.

\begin{tabular}{lcccc}
\hline Variety & 1 & 2 & 3 & 4 \\
\hline Esser & 0,58 & 8,3 & 17,1 & 1,4 \\
Malosan & 0,66 & 5,5 & 12,0 & 4,8 \\
Kinman & 0,61 & 7,3 & 19,8 & 2,8 \\
Lewis & 0,68 & 5,9 & 16,2 & 2,5 \\
Santa Cruz & 0,50 & 6,8 & 10,2 & 2,6 \\
\hline
\end{tabular}

\subsection{Production and qualitative parameters}

Seed yield did not show any significant difference between varieties $\left(2,400 \mathrm{~kg} \mathrm{ha}^{-1}\right.$ on average). Malosan and Santa Cruz showed the higher individual seed weight $(33.9 \mathrm{mg}$ and $32.8 \mathrm{mg}$ respectively), while the lowest was recorded in Esser (26.9 mg) (Fig. 5).

Seed protein content of the five varieties showed significant differences. The highest protein content was detected for Lewis and Esser $(35.6 \% \pm 0.24$ and $34.7 \% \pm 0.21$ respectively); Santa Cruz and Malosan showed intermediate values $(32.1 \% \pm 0.39$ and $29.7 \% \pm 1.48$ respectively), while the lowest was found in Kinman $(26.9 \% \pm 0.12)$. Seed fibre content did not show any difference among the varieties, with an average value of $11.3 \% \pm 0.37$.

\section{Discussion and conclusion}

The results of this study give original indications of biomass accumulation and seed yield of guar in the Mediterranean area and contribute to a better knowledge of this crop. No many research data on yield and biomass response of guar in this region are available. Guar cultivated in Mediterranean environment showed a very good adaptation. Significant differences between varieties were found for plant height, leaf number, branch number, dry biomass and individual seed weight, even if they did not result in differences among seed yield.

Our results demonstrated that accumulation of dry weight was quite slow during the first 40 DAS, 20 days less compared to what reported by Jackson and Doughton (1982). Dry biomass accumulation showed a growing season of about 120 days for all the varieties, with rapid growth between 40 and 70 DAS. The maximum dry weight increment (registered between 55 and 70 DAS) was directly linked to the weight incre- 


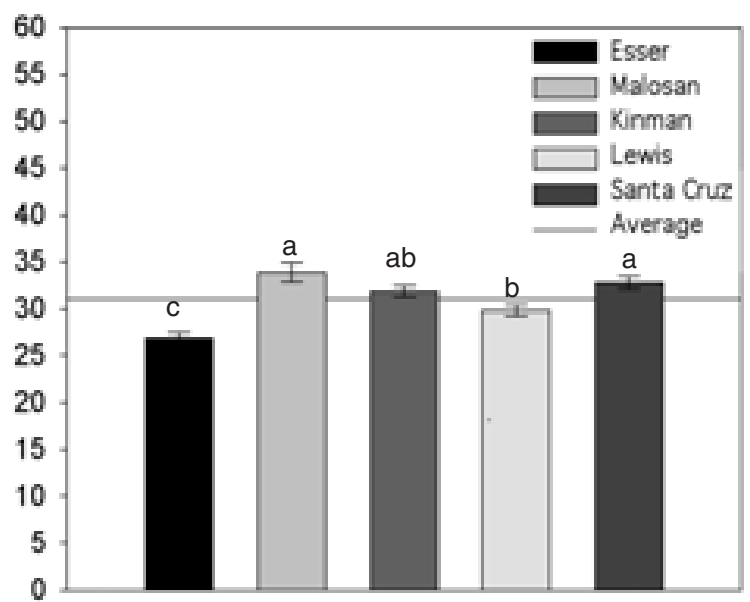

Figure 5. Dry individual seed weight for each variety. Vertical bars indicate standard error. Different letters are significantly different $(\mathrm{P}<0.05)$.

ment of pods, even in presence of the dropping of senescent leaves. Pods, in fact, started to grow after 55 DAS and continued until harvest. From CGR analysis it emerged the different growth behaviour of studied varieties: Kinman had a fast growth rate above all in the $3^{\text {rd }}$ period, while Malosan showed high crop growth rate until the end of crop season. Santa Cruz has a less heavy pods, but with a higher individual seed weight. Stem and branches gave a very little contribute to he total dry matter during all the biological cycle.

Seed yield of guar reported in literature are highly variable, ranging from less than $1,000 \mathrm{~kg}$ $\mathrm{ha}^{-1}$ without irrigation (Tucker and Foraker, 1975) to $5,000 \mathrm{~kg} \mathrm{ha}^{-1}$ in irrigated row plots (Beech et al., 1989). In this experiment, guar showed an average seed production of $2,400 \mathrm{~kg} \mathrm{ha}^{-1}$, that represents a good production compared to the most of the reported yields (Jackson and Doughton, 1982; Kumar and Singh, 2002). These results may be due to favourable environmental conditions and to water not limiting production and also because this crop, especially in India, is often relegated to poorer land (Jackson and Doughton, 1982). Moreover the high temperatures and low relative humidity of Mediterranean environment are able to inhibit Alternaria cyamopsidis disease (Saharan and Saharan, 2004), that strongly limits the grain production in rainy climate (Yogendra et al., 1995).

In agreement with Losavio et al. (2002), little variation between varieties was observed in seed yield. On the contrary, Alexander et al.
(1988) in irrigated plots in Arizona reported that Lewis increased guar seed production up to $25 \%$ over Kinman and Santa Cruz. Malosan, Santa Cruz and Kinman gave greater individual seed weight, but, due to a compensative number of pods per plant (data not showed), all the varieties gave similar seed yields.

Compared to reports from Batthi and Sial (1971) and Elsheikh et al. (1999), a greater seed protein content was measured in the present experiment. Similar protein content was detected in guar by Jain et al. (1987). Individual seed weight and seed protein content seem to be negatively correlated: the two varieties that showed the highest percentage of protein (Esser and Lewis) were also the lowest in dry individual seed weight.

Among the industrial crops, guar is of particular interest for Mediterranean environments for its high seed yield and quality. The high number of leaves (detected particularly in Malosan, Esser and Santa Cruz) confirm the validity of guar not only for grain, but as a multipurpose crop. With its 120 days of growing period, guar can be classified among the short duration crops, confirming to be a suitable alternative crop for these areas. Moreover, nitrogen fixation allows successfully rotation with wheat, cotton and pearl-millet (Allen, 1964; Tucker and Foraker, 1975; Saxena et al., 1997). The knowledge of a rapid growth period can lead to a more opportune fertilization and irrigation management technique in this crop.

Further studies are required to evaluate the best management techniques in semi arid environments in order to increase production and quality of grain and reduce water supply.

\section{Acknowledgements}

We like to thank Calvin Trostle and Michael Abberton for their useful scientific and linguistic suggestions.

\section{References}

Alexander W.L., Bucks D.A., Backhaus R.A. 1988. Irrigation water management for guar seed production. Agron. J., 80:447-453.

Allen G.H. 1964. Guar shows promise. Qld. Agric. J., 90:224-227.

AOAC, 1995. Official methods of analysis ( $16^{\text {th }}$ ed.), As- 
sociation of Official Analytical Chemists, Washington, DC

Ashraf M.Y., Akhtar K., Sarwar G., Ashraf M. 2005. Role of the rooting system in salt tolerance potential of different guar accessions. Agron. Sustain. Dev., 25:243-249.

Beech D.F., Stutzel H., Charles-Edwards D.A. 1989. Yield determinants of guar (Cyamopsis tetragonolo$b a)$ : 1. Grain yield and pod number. Field Crops Research, 21:29-37.

Bhatti M.B., Sial M.B. 1971. Guar - its utility in food and non food industries. Pakistan J. Sci., 23:1-5.

Doorenbos J., Kassam A.H. 1979. Yield response to water. Irrigation and drainage. Paper N. 33, FAO, Rome.

Elsheikh E.A.E., Ibrahim K.A. 1999. The effect of Bradyrhizobium inoculant on yield and seed quality of guar (Cyamopsis tetragonoloba L.). Food Chemistry, 65:183-187.

Francois L.E., Donovan T.J., Maas E.V. 1990. Salinity effects on emergence, vegetative growth and seed yield of guar. Agron. J., 82:587-592.

Jackson K.J., Doughton J.A. 1982. Guar: a potential industrial crop for dry tropics of Australia. J. Austr. Inst. Agr. Sci., 42:17-31.

Jain V., Yadav B.D., Sharma B.D., Taneja K.D. 1987. Effect of dates of sowing, row spacing and varieties on yield and quality of clusterbean (Cyamopsis tetragonoloba (L.) Taub.). Indian J. Agron., 32:378-382.

Losavio N., Infantino A., Vonella V. 1995. Guar: una potenziale coltura industriale dell'area mediterranea. Informatore Agrario, 39:41-43.

Losavio N., Ventrella D., Vonella A.V. 2002. Adattabilità ambientale e potenzialità produttiva del guar coltivato in regime irriguo nell'Italia meridionale. Rivista di Agronomia, 36:171-175.

Kumar D., Singh N.B. 2002. Guar in India. Scientific Publishers, Jodhopur.

Mehta D.R., Ramakrishnan C.V. 1957. Studies of guar seed (Cyammopsis psoralioides). Journal of American Oil Chemistry Society, 34:459-461.

Omer E.A., Fattah A., Razin M., Ahmed S.S. 1993. Effect of cutting, phosphorus and potassium fertilization on guar (Cyamopsis tetragonoloba) in newly reclaimed soil in Egyptian. Plant Food for Human Nutrition, 44:277-284.

Saharan M.S., Saharan G.S. 2004. Influence of weather factors on the incidence of Alternaria blight of Cluster bean (Cyamopsis tetragoloba (L.) Taub.) on varieties with different susceptibilities. Crop Protection, 23:1223-1227.

Saxena A., Singh D.V., Joshi N.L. 1997. Effects of tillage and cropping systems on soil moisture balance and pearl millet yield. Journal of Agronomy and Crop Science, 178:251-257.

Tucker B., Foraker R. 1975. Cotton and grain sorghum yields following guar and cowpeas compared to continuous cropping. Oklahoma Agricultural Experimental Station Research.

Wetselaar R. 1967. Estimation of nitrogen fixation by four legumes in a dry monsoonal area of north-western Australia. Australian Journal of Experimental Agriculture and Animal Husbandry, 7:518-522.

Whistler R.L., Hymowitz T. 1979. Guar: Agronomy, production, industrial use, and nutrition. Purdue University Press, West Lafayette, Indiana.

Whyte R.O., Nilsson-Leissner G., Trumble H.C. 1953. Legumes in agriculture. Agricultural Study N. 21, F.A.O, Rome.

Yogendra S., Kushwaha K.P.S., Chauhan S.S. 1995. Epidemiology of Alternaria leaf blight of cluster bean caused by Alternaria cyamopsidis. Annals of Plant Protection Science, 3:171-172.

Zambrano F., Despinoy P., Ormenese R.C.S.C., Faria E.V. 2004. The use of guar and xanthan gums in the production of light low fat cakes. Int. J. Food Sci. Tech., 39:956-966. 